\title{
Penerapan Budaya Ramah Lingkungan pada Siswa-Siswi Sekolah Gajahwong: Pendidikan Alternatif Berbasis Eco-Friendly
}

\author{
Ira Karunia, Isna Ardyani Fataya, Maria Ardianti Kurnia Sari, Amin Basuki \\ Magister Pengkajian Amerika, Fakultas Ilmu Budaya, Universitas Gadjah Mada \\ Korespondensi: iraa.karunia@gmail.com
}

Tim Pengabdian Masyarakat

Seluruh mahasiswa S-2 Pengkajian Amerika Tahun Ajaran 2018 dan 2019

\begin{abstract}
Sekolah Gajahwong is an informal school which is located in Yogyakarta and has the main concern to educate the students to save the planet Earth from plastic trash by reusing, reducing, and recycling. Through the main concern, they keep improving to do some activities that can make the students to have willingness by applying the eco-friendly concepts. The methods are done by applying the ecofriendly concepts, for example making decorations from bottle caps, making cardboard train, and planting fruits and vegetables. Those activities become the application of Bloom's taxonomy (1956); Cognitive and Psychomotor Domain. Students of American Studies Master's Program try contribute and give their hand to achieve the goals through an annual event in Charity Act. As the result, Charity Act gives Sekolah Gajahwong and American Studies Master's Program's students to build a good relationship among others. Also, they can apply the concepts into the classroom learning activities including their everyday life. The successful of Charity Act is due to a good teamwork between all American Studies Master's students from batch 2018 and 2019 who are supported by lecturers.
\end{abstract}

Keywords: Sekolah Gajahwong, education, environment, eco-friendly, cognitive

\begin{abstract}
Abstrak
Sekolah Gajahwong adalah sekolah informal di Kota Yogyakarta yang berfokus untuk mengedukasi siswa dalam menyelamatkan bumi dari sampah plastik dengan cara menggunakan ulang, mengurangi, dan mendaur ulang. Hal ini terus ditingkatkan agar dapat membuat siswa memiliki keinginan untuk menerapkan konsep ramah lingkungan. Metode-metode yang digunakan dalam pengaplikasian konsep ramah lingkungan, antara lain, adalah membuat dekorasi dinding dari tutup botol, membuat kereta dari kardus, dan menanam buah dan sayur. Hal tersebut selaras dengan domain kognitif dan psikomotor yang dalam taksonomi Bloom (1956), yakni sebuah pendidikan alternatif yang berfokus pada bagaimana siswa dapat mengaplikasikan konsep atau teori. Mahasiswa S-2 Pengkajian Amerika membantu Sekolah Gajahwong untuk mencapai tujuannya melalui sebuah acara tahunan yang disebut Charity Act. Hasil yang berhasil dicapai dari Charity Act adalah terbangunnya relasi yang baik antara siswa-siswi Sekolah Gajahwong dan Tim PKM S-2 Pengkajian Amerika serta mereka dapat menerapkan konsep ramah lingkungan dalam kegiatan belajar dan keseharian hidup. Kesuksesan Charity Act juga dipengaruhi oleh kerja sama tim PKM S-2 Pengkajian Amerika tahun ajaran 2018 dan 2019 serta dukungan dari pihak dosen.
\end{abstract}

Kata kunci: Sekolah Gajahwong, pendidikan, ramah lingkungan, kemampuan kognitif 


\section{Pendahuluan}

Akibat dari kerusakan dan pencemaran alam semakin dapat dirasakan belakangan ini. Polusi air, menurunnya kualitas dan persediaan air di dunia, polusi udara, hutan yang semakin menggundul, perubahan iklim, keanekaragaman hayati yang terancam, maupun kebakaran hutan adalah beberapa contoh kerusakan dan pencemaran alam yang terjadi di berbagai belahan dunia. Menyikapi hal ini, kesadaran manusia untuk hidup dengan mempertimbangkan keberlangsungan alam dan lingkungan semakin dibutuhkan. Perlu adanya edukasi kepada masyarakat tentang pentingnya ekosistem yang terawat terkait dengan masa depan umat manusia. Keberadaan internet diharapkan mampu memfasilitasi distribusi informasi mengenai isu lingkungan sehingga masyarakat dengan akses pengetahuan tersebut akan merespons dengan upaya-upaya menuju budaya atau tata cara hidup yang ramah lingkungan. Kepedulian dan aksi mengenai lingkungan serta alam dewasa ini bukan merupakan tanggung jawab gerakan atau komunitas yang bergerak di bidang lingkungan semata, melainkan tanggung jawab seluruh lapisan masyarakat.

Program Studi S-2 Pengkajian Amerika, Universitas Gadjah Mada melirik isu lingkungan sebagai hal yang perlu diperhatikan lebih lanjut. Sudah seharusnya akademia tidak hanya fokus terhadap teori, tetapi juga praktik. Dalam ranah S-2 Pengkajian Amerika, mahasiswa/mahasiswi beserta dosen berperan aktif tidak hanya dalam praktik untuk mengedukasi, tetapi juga menerapkan konsep ke dalam sebuah praktik nyata yang bermanfaat bagi masyarakat. Menoleh ke belakang, para pemikir besar Amerika seperti Henry David Thoreau dan Ralph Waldo Emerson percaya tentang pentingnya keselarasan atau harmoni antara manusia dan alam serta lingkungannya. Buah pikiran mereka berujung pada filosofi Transcendentalism, yang pada perkembangannya memengaruhi aspek lain dalam masyarakat Amerika, seperti cara hidup yang menghormati alam dan ramah terhadap lingkungan. Pesatnya industrialisasi di Amerika dan dampak yang buruk terhadap lingkungan juga direspons dengan munculnya berbagai undang-undang yang melindungi alam serta gerakan-gerakan sadar lingkungan. Mempelajari Amerika dalam ranah Pengkajian Amerika berarti turut pula mempelajari pentingnya menjaga lingkungan sebagaimana yang telah dikemukakan oleh para intelektual Amerika. Pengkajian Amerika sebagai bidang ilmu memberikan pengayaan wawasan, perspektif, dan kepekaan dalam kaitannya dengan isu lingkungan pada dosen dan tim PKM S-2 Pengkajian Amerika Universitas Gadjah Mada.

Dalam tatanan dunia yang semakin terhubung dengan adanya globalisasi, isu lingkungan menjadi sebuah isu global. Dengan kata lain, seluruh warga dunia memiliki tanggung jawab untuk bersama-sama memperhatikan hal tersebut. Atas dasar keprihatinan dan kepedulian akademia sebagai anggota masyarakat dalam skala lokal dan global maka pada tahun 2019, dosen serta tim PKM S-2 Pengkajian Amerika mengadakan kegiatan PKM di Sekolah Gajahwong yang berkaitan dengan isu lingkungan. Kegiatan PKM S-2 Pengkajian Amerika ini dikenal dengan julukan Charity Act. Charity Act 2019 kali ini mengusung tema "Penerapan Budaya Ramah Lingkungan pada Siswa-Siswi Sekolah Gajahwong: Pendidikan Alternatif Berbasis Eco-Friendly."

Sekolah Gajahwong merupakan sekolah nonformal yang berlokasi di Jl. Rukun Pertiwi No. 51, Muja Muju, Kec. Umbulharjo, Kota Yogyakarta, Daerah Istimewa 
Yogyakarta. Mengapa sekolah ini memiliki julukan Sekolah Gajahwong? Hal ini karena lokasi sekolah berdekatan dengan Sungai Gajahwong yang membelah Kota Yogyakarta. Mayoritas siswa-siswi sekolah tersebut datang dari keluarga yang berprofesi sebagai pemulung. Oleh karena itu, dapat dikatakan bahwa siswa-siswi Sekolah Gajahwong termasuk kategori tertinggal, terluar, dan terpinggirkan, dengan menimbang latar belakang sosio-kultural mereka. Sekolah Gajahwong merintis konsep budaya ramah lingkungan. Akan tetapi, sekolah ini memiliki keterbatasan karena belum mengimplementasikan budaya ramah lingkungan ke dalam keseharian mereka.

Penerapan konsep eco-friendly di Sekolah Gajahwong ini dinilai masih memiliki potensi untuk dikembangkan sehingga dosen dan tim PKM S-2 Pengkajian Amerika melihat adanya kesempatan untuk berkontribusi dalam masyarakat tersebut dengan membawa added values. Tim PKM memiliki misi untuk memotivasi siswa-siswi Sekolah Gajahwong dan menumbuhkan budaya ramah lingkungan melalui materi yang disimulasikan dalam bentuk kegiatan seperti meminimalisasi sampah, menggunakan media pengajaran dari barang bekas pakai, dan mengurangi penggunaan plastik dalam aktivitas sehari-hari. Dalam penyampaian materi dan kegiatan, bahasa Inggris juga akan diperkenalkan kepada siswa-siswi Sekolah Gajahwong guna menyiapkan keterlibatan mereka dalam tatanan dunia.

Pada akhirnya, tujuan dari program pengabdian kepada masyarakat ini adalah untuk membuat siswa-siswi Sekolah Gajahwong sadar akan pentingnya menerapkan budaya ramah lingkungan dalam kegiatan belajar dan kebiasaan sehari-hari. Selain itu, harapan dari tim PKM bersama siswa-siswi Sekolah Gajahwong adalah mengajak generasi muda untuk dapat tetap menjaga keseimbangan ekosistem, memelihara dan merawat alam, dan juga dapat meneruskannya kepada lingkungan sekitar. Hasil yang diharapkan dari kegiatan Pengabdian Masyarakat: Charity Act 2019 ini adalah terbentuknya komunitas sadar lingkungan yang akan secara konsisten menerapkan budaya ramah lingkungan pada praktik kehidupan sehari-hari.

\section{Pedekatan Pelaksanaan Program}

Tim pelaksana pengabdian masyarakat memberikan materi penguatan kepada siswa-siswi sekolah untuk menerapkan konsep budaya ramah lingkungan yang telah dirintis oleh sekolah. Fokus kegiatan pengabdian adalah harapan supaya siswa-siswi Sekolah Gajahwong mampu menginternalisasi konsep budaya ramah lingkungan dan mempraktikkannya dalam kehidupan sehari-hari. Hal ini diterapkan melalui kegiatan bermain sambil belajar dan diharapkan siswa-siswi Sekolah Gajahwong dapat menerapkan kegiatan tersebut ke depannya.

Metode yang digunakan adalah pelatihan dan pendampingan pada siswa-siswi Sekolah Gajahwong. Rentang usia siswa-siswi Sekolah Gajahwong terbilang muda, yaitu pada usia 3-7 tahun. Oleh karena itu, memberikan pendampingan melalui kegiatan bermain sambil belajar dapat dikatakan sebagai pendekatan yang baik. Menurut ahli Psikologi asal Jerman, Erik Erikson, ada delapan tahap perkembangan psikologi. Perkembangan psikologi ini dapat membentuk kepribadian sejak usia dini hingga dewasa. Erikson berpendapat bahwa setiap manusia harus melewati beberapa tahap di umur tertentu untuk mencapai jenjang kehidupan tertinggi. Erikson mengklasifikasikan 
perkembangan manusia menurut rentang usia. Pada jenjang usia $3-5$ tahun, Erikson juga mempercayai bahwa inisiatif dan perasaan bersalah anak-anak terbentuk pada usia ini (dalam McLeod, 2018) sehingga pada usia ini pula, anak-anak dapat menentukan tujuan hidupnya mendatang.

Selain itu, Benjamin S. Bloom (1956) juga berpendapat mengenai adanya tiga domain dalam taksonominya yang dapat diklasifikasikan dalam tingkat kompleksitas dan spesifitas, di antaranya, adalah Cognitive Domain (Ranah Kognitif), Affective Domain (Ranah Afektif), dan Psychomotor Domain (Ranah Psikomotor) (dalam The Performance Juxtaposition Site, 1995a). Dalam kegiatan bersama siswa-siswi Sekolah Gajahwong ini, metode yang diterapkan cenderung berfokus pada Cognitive Domain (Ranah Kognitif) dan Psychomotor Domain (Ranah Psikomotor). Menurut Bloom (1956), Cognitive Domain (Ranah Kognitif) terdiri atas enam hal, yakni Pengetahuan (Knowledge), Pemahaman (Comprehension), Aplikasi (Application), Analisis (Analysis), Sintesis (Synthesis), dan Evaluasi (Evaluation), (The Performance Juxtaposition Site, 1995a). Namun, dari keenam tahapan pada Ranah Kognitif tersebut, menurut Patricia Amstrong (2001), seorang mantan Asisten Direktur pusat Pendidikan Universitas Vanderbilt, mengemukakan bahwa terdapat beberapa revisi yang tidak jauh menyimpang dari tahapan Ranah Kognitif sebelumnya, yakni Menciptakan (Creating), Mengevaluasi (Evaluating), Menganalisis (Analyzing), Mengaplikasikan (Applying), Memahami (Understanding), dan Mengingat (Remembering). Dari keenam tahapan ini ditunjukkan bahwa proses ranah kognitif manusia didasari dengan adanya pengetahuan atau membuat sebuah kasus, yang kemudian proses dan hal tersebut akan berkembang dengan membentuk tahapantahapan berikutnya, yang dapat disimpulkan menjadi evaluasi pembelajaran atau dapat diingat oleh setiap siswa/siswi yang dapat memecahkan kasus tersebut.

Melihat enam tahapan Ranah Kognitif maka keenam hal tersebut secara otomatis akan diterapkan dalam Ranah Psikomotor karena didasarkan pada apa yang siswa/siswi lihat. Apabila hal tersebut menarik perhatian mereka, mereka akan menanggapi hal tersebut dengan gerakan tubuh atau psikomotorik. Adapun menurut The Performance Juxtaposition Site (1995b), Ranah Psikomotor milik Bloom (1956) juga dibagi menjadi tujuh tahapan, yakni Persepsi (Perception), Kesiapan (Set), Respons Terpimpin (Guided Response), Mekanisme (Mechanism), Respons Tembak yang Kompleks (Complex Overt Response), Penyesuaian (Adaptation), dan Penciptaan (Origination).

\section{Pelaksanaan Program}

Tim pengabdian mengadakan survei lapangan untuk melakukan pengenalan lingkungan, komunikasi kepada pihak sekolah, serta melakukan pematangan konsep pengabdian. Setelah melakukan survei lapangan, tim melakukan rapat pembentukan panitia dan mempersiapkan kebutuhan serta materi pengabdian. Dari hasil survei tersebut, ditentukan program apa yang bisa diterapkan seperti halnya jenis-jenis permainan yang bisa diminati oleh para siswa Sekolah Gajahwong karena harus disesuaikan dengan rentang usia mereka, yakni 3-7 tahun. Selain itu, tim PKM S-2 Pengkajian Amerika juga mengembangkan ide agar para siswa Sekolah Gajahwong bisa menerapkan kegiatan positif melalui kegiatan bermain sambil belajar ini.

Sekolah Gajahwong adalah sekolah informal yang memiliki panduan atau kurikulum 
sendiri. Setiap semester, setiap kelas memiliki tema yang berbeda-beda untuk dua kelas yang berbeda. Pada semester genap tahun ajaran 2019/2020 ini, siswa-siswi Kelas Akar memiliki tema buah-buahan. Kemudian, anak-anak dari Kelas Rumput mendapat tema kereta. Pemilihan tema dilakukan atas dasar pertimbangan anak-anak terhadap hal-hal yang mereka sukai.

Sebelum memulai kegiatan di Sekolah Gajahwong, panitia dan peserta kegiatan berkumpul di gedung FIB UGM untuk menghadiri briefing pelaksanaan acara. Setelahnya, panitia berangkat bersama ke tempat dilaksanakannya kegiatan dengan dipandu oleh dua mahasiswa S-2 Pengkajian Amerika, yaitu Ira Karunia dan Nabil Bakri. Sesampainya di tempat pelaksanaan acara, rangkaian pembukaan acara di Sekolah Gajahwong dibuka dengan doa khidmat.

Perkenalan antara siswa-siswi Sekolah Gajahwong dan tim PKM S-2 Pengkajian Amerika yang didampingi oleh staf Sekolah Gajahwong pun berjalan dengan suasana yang akrab dan hangat. Panitia juga memandu warming up berupa tarian kecil mengikuti lagu yang sudah dipersiapkan guna membangun kedekatan yang baik dengan siswa-siswi Sekolah Gajahwong dan menyuntikkan semangat sebelum memulai aktivitas utama. Robert E. Slavin (2006) di dalam bukunya yang berjudul Educational Psychology: Theory and Practice 8th edition mengemukakan bahwa aktivitas seperti yang dilakukan oleh para siswa Sekolah Gajahwong ini dapat dikategorikan dalam sistem penilaian atau assessment. Tentu saja, assessment yang diperoleh para siswa Sekolah Gajahwong tersebut didasari oleh assessment objektif di dalam Cognitive Domain (Ranah Kognitif). Berdasarkan instruksi yang diberikan oleh tim PKM S-2 Pengkajian Amerika yang ingin membuat suasana menjadi hangat dan akrab, aktivitas menari bersama dijadikan sebagai awal perkenalan dengan siswa-siswi Sekolah Gajahwong karena sesuai dengan yang dikatakan oleh Amstrong (2001) bahwa menari bersama merupakan bentuk kemampuan kognitif, yakni mengevaluasi, menganalisis, mengaplikasikan, dan memahami. Aktivitas seperti menari merupakan salah satu bentuk respons kognitif siswa-siswi Sekolah Gajahwong. Dari ketertarikan tersebut, dilanjutkan dengan gerakan tarian Baby Shark dan Gummy Bear yang mereka lihat di layar proyektor, yang seolah menarik mereka untuk ikut serta dalam menari, membuat hal ini menjadi salah satu bentuk aktivitas psikomotorik.

Setelah rangkaian pembukaan acara selesai, siswa-siswi Sekolah Gajahwong yang terdiri atas dua Kelas Akar dan Rumput dibagi lagi menjadi empat kelompok sehingga dihasilkan dua kelompok di Kelas Akar dan dua kelompok di Kelas Rumput. Rentang usia anak-anak di Kelas Akar yaitu 3-4 tahun, sedangkan anak-anak di Kelas Rumput berusia 5-7 tahun. Adapun rangkaian kegiatan yang dilakukan adalah melakukan eksekusi permainan yang sudah direncanakan. Dalam hal ini ada empat permainan besar yang dilakukan, yakni meliputi permainan ular tangga, menebak buah, bercocok tanam, dan membuat kereta dari kardus bekas.

Kegiatan yang dilakukan oleh Kelas Akar dan Kelas Rumput masing-masing didampingi oleh empat pendamping dari tim PKM S-2 Pengkajian Amerika. Total pendamping di dalam kelas adalah delapan orang. Kemudian, di setiap kelas dan sesi terdapat dua orang guru utama yang akan menjelaskan tentang permainan kepada anak-anak.

Sesi pertama di Kelas Akar adalah bercocok tanam. Guru utama sudah bersiap memberikan penjelasan kepada anak-anak di kebun sekolah. Para pendamping 


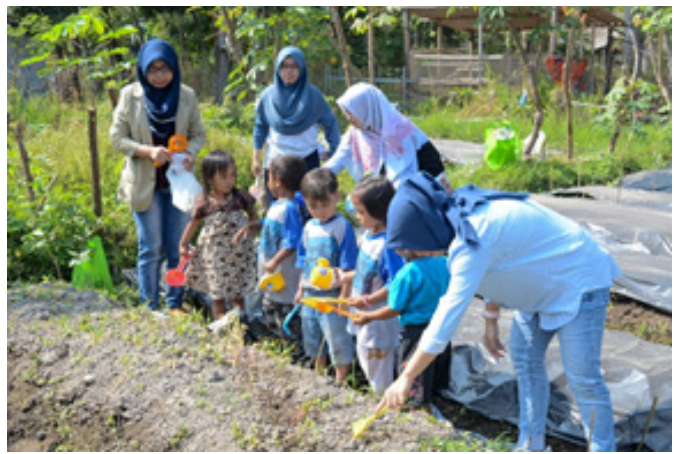

Gambar 1. Kelas Akar melakukan kegiatan bercocok tanam di kebun.

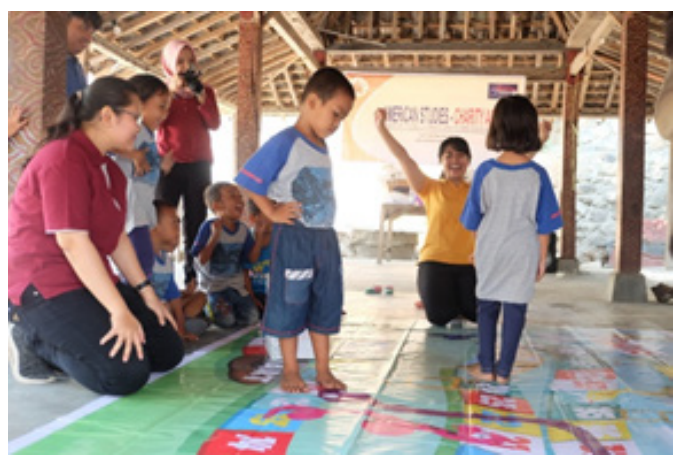

Gambar 3. Kelas Rumput bermain ular tangga di pendopo.

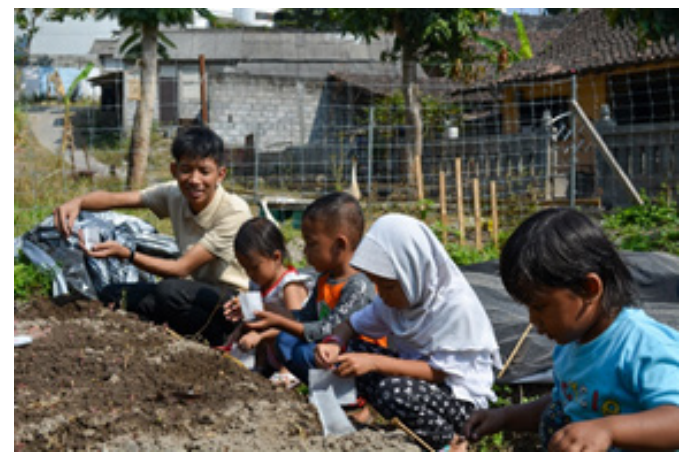

Gambar 2. Kelas Akar melakukan kegiatan bercocok tanam di kebun.

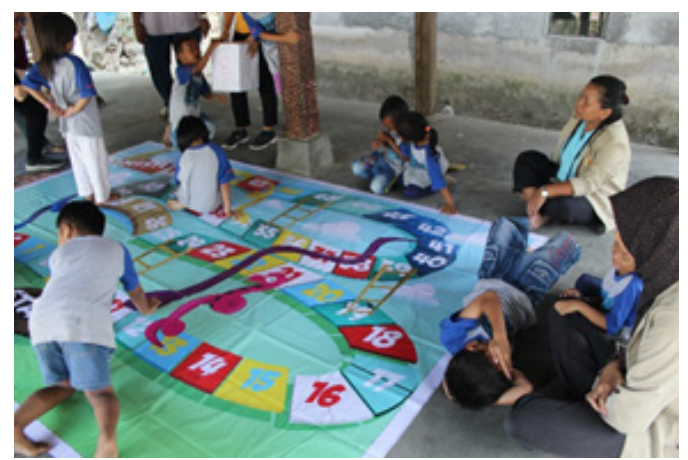

Gambar 4. Kelas Rumput bermain ular tangga di pendopo.

mendampingi anak-anak menuju kebun untuk melakukan kegiatan bercocok tanam. Adapun tanaman yang sudah pilih untuk ditanam oleh anak-anak adalah jeruk lemon, jambu air, dan jambu biji. Pertama, guru akan menjelaskan buah yang akan ditanam, manfaat buah, dan cara menanam buah, serta menjelaskan waktu yang dibutuhkan oleh tanaman tersebut untuk tumbuh. Respons siswa-siswi Sekolah Gajahwong sangat antusias. Mereka menunjukkan antusiasme untuk mencangkul tanah, berinisiatif menyemai bibit tanaman, berlomba-lomba menanam pohon, dan bergiliran menyirami tanah yang sudah ditanami bibit maupun pohon. Setelah kegiatan bercocok tanam selesai, para pendamping menambah pengetahuan para siswa Sekolah Gajahwong dengan mengajari nama-nama tanaman tersebut dalam bahasa Inggris.

Pada jam yang sama, anak-anak dari Kelas Rumput juga sedang memainkan permainan ular tangga. Permainan ular tangga dipilih karena sederhana atau dapat dimainkan oleh semua anak dan juga mengajak anak-anak untuk bergerak melompati satu kotak ke kotak anak tangga lainnya. Permainan tersebut adalah inovasi pembelajaran mengenai lingkungan sebab siswa-siswi harus menjawab pertanyaan seputar lingkungan untuk dapat berpindah dari kotak yang satu ke kotak yang lain. Para siswa menunjukkan semangat belajar yang tinggi dan respons yang baik terhadap pertanyaan dan materi seputar lingkungan yang disampaikan oleh para pendamping.

Gambar 1, 2, 3, dan 4 tersebut menampilkan kegiatan pertama yang dilakukan oleh Kelas Akar dan Rumput. Konsep bermain sambil belajar menjadi tujuan utama 
untuk mengenalkan kepada siswa-siswi tentang pentingnya bersosialisasi dan mengenal lingkungan sekitar, menjalin keakraban pada sesama, dan tentu saja mengolah psikomotorik mereka. Menurut Bloom (1956), Ranah Psikomotorik menjadi bagian dari kegiatan ini karena konsep bermain dan melakukan pergerakan fisik diterapkan di dalamnya. Tujuh tahapan yang terdapat dalam Ranah Psikomotor, di antaranya, adalah Persepsi (Perception), Kesiapan (Set), Respons Terpimpin (Guided Response), Mekanisme (Mechanism), Respons Tembak yang Kompleks (Complex Overt Response), Penyesuaian (Adaptation), dan Penciptaan (Origination) (dalam The Performance Juxtaposition Site, 1995b).

Sebelum memulai sesi kedua, anak-anak akan diminta untuk istirahat dan menikmati camilan yang sudah disediakan. Permainan sesi kedua dilakukan di dalam kelas masing-masing. Setelah bercocok tanam di kebun, anak-anak Kelas Akar diajak untuk lebih mematangkan konsep yang telah mereka dapatkan dengan cara melanjutkan permainan mencari buah dan menebak nama buah. Para pendamping membuat permainan dengan menyembunyikan miniatur buah-buahan yang dapat ditemukan di lingkungan sekitar di berbagai sudut ruang kelas. Para siswa mencari buah-buahan tersebut setelah mampu menjawab dan menebak buah apa yang disembunyikan oleh para pendamping. Permainan ini merupakan pengenalan lebih jauh kepada para siswa mengenai lingkungan sekitar mereka, termasuk keragaman hayati yang ada, sehingga diharapkan kepedulian terhadap lingkungan dapat terinternalisasi.

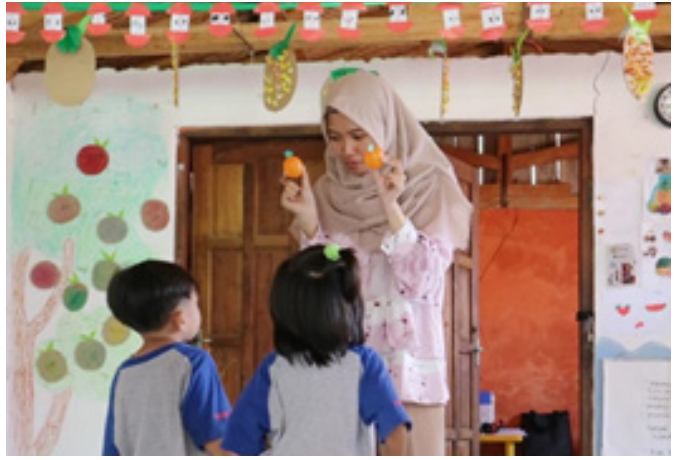

Gambar 5. Kelas Akar bermain tebak buah-buahan di kelas.

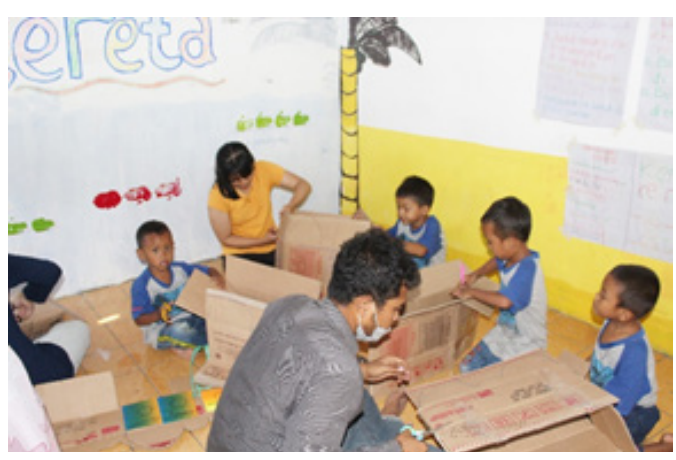

Gambar 7. Kelas Rumput membuat kereta dari kardus.

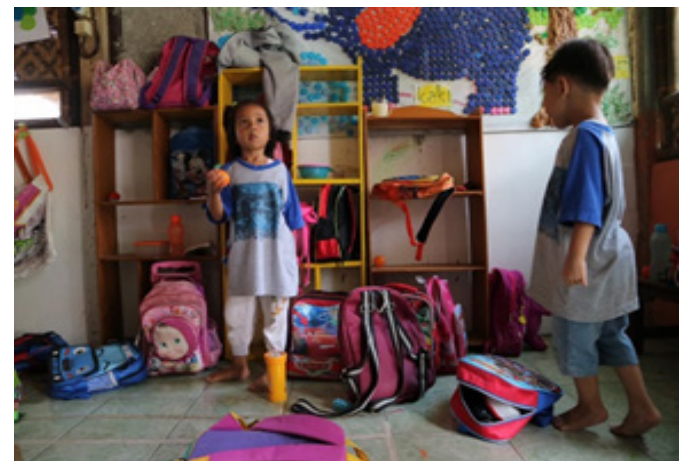

Gambar 6. Kelas Akar bermain tebak buah-buahan di kelas.

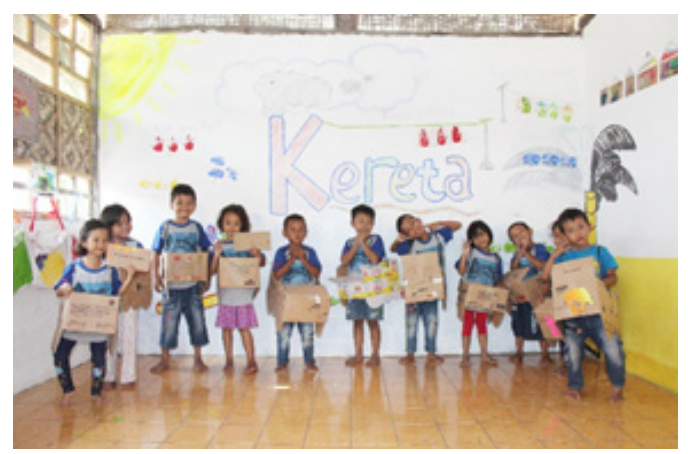

Gambar 8. Kelas Rumput membuat kereta dari kardus. 
Anak-anak Kelas Akar diajak untuk mencari buah-buahan yang sudah disembunyikan di dalam kelas. Kemudian, anak-anak diminta untuk menebak nama buah tersebut. Selanjutnya, guru akan bertanya manfaat dari buah tersebut.

Di Kelas Rumput, anak-anak diajak untuk membuat kereta dari kardus. Aktivitas ini bertujuan untuk menanamkan nilai pengurangan sampah melalui daur ulang barang untuk menjaga lingkungan. Para pendamping menunjukkan langkah serta membimbing siswa-siswi untuk membuat prakarya tersebut. Para siswa menunjukkan antusiasme dan kepekaan yang tinggi dalam beraktivitas. Dalam hal ini, guru-guru pendamping mengalami sedikit kesulitan dalam memotong kardus, yang juga memakan waktu cukup lama. Walaupun demikian, anak-anak di Kelas Rumput sangat gembira dan senang karena dapat membuat kereta bersama guru-guru pendamping dari tim PKM S-2 Pengkajian Amerika. Keseruan itulah yang dapat membuat guru-guru pendamping semakin akrab dan mengenal para siswa.

Gambar 5, 6, 7, dan 8 di atas menunjukkan kesiapan Kelas Akar dan Rumput dalam kegiatan menebak buah-buahan serta membuat kereta dari kardus. Ranah Kognitif menjadi bagian dari aktivitas ini. Hal ini ditunjukkan dengan cara siswa-siswi Sekolah Gajahwong dalam menanggapi aktivitas yang diberikan oleh tim PKM S-2 Pengkajian Amerika. Menurut Amstrong (2001), terdapat revisi dalam Ranah Kognitif, di antaranya mencipta (creating), mengevaluasi (evaluating), menganalisis (analyzing), mengaplikasikan (applying), memahami (understanding), dan mengingat (remembering). Kemampuan kognitif setiap siswa di Sekolah Gajahwong sangat terbantu dengan aktivitas yang melibatkan ilustrasi nyata, seperti bentuk buah-buahan plastik dan cara membuat kereta dengan kardus. Hal-hal tersebut tentu saja akan memberikan hasil akhir berupa hal yang nantinya akan mereka ingat ketika mereka mempelajari hal-hal baru lainnya.

Setelah semua permainan selesai dilakukan, acara ditutup dengan pembagian reward untuk anak-anak yang berisi perlengkapan alat tulis seperti buku, pulpen, pensil, serta botol minuman yang dapat mereka gunakan sebagai bekal di sekolah. Tim PKM juga memberikan kesimpulan dari keseluruhan aktivitas yang telah dilakukan untuk menekankan tujuan dari tiap-tiap kegiatan yang telah mereka laksanakan dan manfaatnya pada masa mendatang, seperti menanam dan merawat tanaman sebagai paru-paru dunia serta dapat dikonsumsi buahnya untuk memberi asupan vitamin bagi tubuh dan lain-lain.

\section{Refleksi Capaian Program}

Ada beberapa tantangan yang dihadapi oleh tim PKM saat bertugas, salah satunya adalah belum lancarnya komunikasi dan adanya tantangan untuk mempersiapkan kegiatan yang sesuai untuk anak-anak. Beberapa tantangan yang diperoleh tersebut membuat tim PKM S-2 Pengkajian Amerika ingin lebih banyak belajar untuk memahami pola pikir anak-anak. Selain itu, walaupun terkendala dalam hal komunikasi, siswa-siswi Sekolah Gajahwong juga menanggapi dengan gembira kedatangan tim PKM dengan adanya beberapa permainan baru yang belum pernah mereka mainkan sebelumnya.

Keberhasilan pelaksanaan PKM di Sekolah Gajahwong diukur dengan selesainya acara tepat waktu dan kelancaran berjalannya seluruh kegiatan. Seluruh panitia juga telah melakukan tugas dengan baik. Hal yang paling utama adalah siswa-siswi Sekolah 
Gajahwong menyambut baik kedatangan tim PKM S-2 Pengkajian Amerika, Universitas Gadjah Mada dengan penuh antusias. Seluruh rangkaian kegiatan juga dapat berjalan lancar karena anak-anak dan pihak sekolah bekerja sama dengan baik untuk mewujudkan acara Charity Act 2019.

Manfaat yang dirasakan dari kegiatan Charity Act 2019 adalah dapat dilaksanakannya salah satu aspek Tri Dharma Pendidikan, yaitu pengabdian kepada masyarakat sebagai seorang akademia. Selain itu, dengan berdinamika bersama orang-orang baru akan membentuk akademia menjadi semakin siap dan matang untuk terjun ke masyarakat dan memiliki bekal untuk bekerja sebagai tim pada masa yang akan datang. Selain itu, manfaat yang dirasakan dari kegiatan Charity Act 2019 adalah dapat membangun kesadaran pada anak-anak untuk lebih mencintai lingkungan dengan cara menerapkan budaya ramah lingkungan, seperti membuang sampah pada tempatnya, meminimalisasi penggunaan sampah dalam kehidupan sehari-hari, serta memanfaatkan barang bekas sebagai sarana dan/atau media belajar. Dengan adanya konsep pengenalan lingkungan yang sudah mulai diterapkan sekolah dalam kurikulum pembelajaran, kami melihat bahwa anak-anak sudah mulai membiasakan diri untuk beradaptasi dalam mencintai lingkungan mereka seperti membawa botol minuman dan makanan setiap hari ketika pergi ke sekolah untuk mengurangi penggunaan botol minuman dan wadah makanan. Selain itu, media permainan yang telah tim PKM pilih juga terbuat dari plastik atau realia buah, bola, dan perlengkapan bercocok tanam, yang nantinya dapat digunakan kembali sebagai media pembelajaran sekolah. Kami memilih hal tersebut atas dasar pertimbangan untuk meminimalisasi kertas yang kami gunakan.

Keberhasilan PKM di Sekolah Gajahwong menjadi pencapaian luar biasa yang diperoleh tim PKM S-2 Pengkajian Amerika Universitas Gadjah Mada. Ada tiga hal utama yang secara tidak langsung diperoleh tim PKM Pengkajian Amerika setelah mengikuti kegiatan Charity Act 2019 atau pengabdian masyarakat, yakni bagaimana mereka mencoba untuk mengolah hati atau rasa serta cara pandang dan pola pikir. Pertama, mengolah hati atau rasa menjadi hal yang penting dalam membangun karakter, terutama bagi tim PKM Pengkajian Amerika, karena kegiatan olah rasa ini akan memberikan rasa peduli dan tanggung jawab yang lebih dalam untuk menjalankan dan melaksanakan tugas pengabdian kepada masyarakat. Olah rasa ini meningkatkan kepedulian bagi mereka yang membutuhkan bantuan meskipun sekadar bantuan sederhana dalam bentuk ilmu atau material. Membagikan semangat belajar yang lebih kepada siswa-siswi Sekolah Gajahwong merupakan salah satu bentuk pelayanan kepada sesama serta membagikan ilmu secara tidak langsung kepada sesama melalui permainanpermainan dan praktik langsung, seperti bermain ular tangga, menebak buah, menanam, dan membuat kereta dari kardus. Kedua, kegiatan Charity Act ini juga mengubah cara pandang serta pola pikir dari tim PKM S-2 Pengkajian Amerika bahwa semua anak berhak memiliki kesempatan untuk menuntut ilmu demi mengembangkan kreativitas dan soft skills yang mereka miliki. Selain itu, kegiatan Charity Act ini juga membuktikan bahwa rasa ingin melayani kepada sesama tentu lebih besar daripada dilayani karena melalui cara pandang dan pola pikir itulah, rasa berbagi kepada sesama tentunya menjadi hal istimewa. 


\section{Penutup}

Berdasarkan pelaksanaan kegiatan pengabdian masyarakat ini, diharapkan hal-hal berikut ini dapat tercapai, yaitu siswa-siswi Sekolah Gajahwong dapat memiliki kesadaran untuk mencintai lingkungan serta mempraktikkan kecintaan terhadap lingkungan dalam kehidupan sehari-hari. Hal itu supaya masyarakat luas dapat memiliki pengetahuan yang tepat guna melalui pendidikan alternatif berbasis eco-friendly secara lebih dalam sebagaimana yang diterapkan oleh Sekolah Gajahwong. Melihat dari apa yang sudah dilaksanakan dan dikerjakan selama PKM di Sekolah Gajahwong, tim PKM percaya bahwa konsep cinta lingkungan sudah mampu diterapkan kepada siswa-siswi Sekolah Gajahwong. Hal ini juga bertujuan agar siswa-siswi Sekolah Gajahwong semakin bisa mempelajari ilmu yang mereka dapatkan tersebut, secara tidak langsung, untuk keberlangsungan masa depan generasi muda pada masa mendatang.

Charity Act sebaiknya tidak hanya menjadi wadah yang memfasilitasi akademia dan masyarakat, tetapi juga dapat digunakan sebagai wadah untuk membukakan jalan bagi para akademia untuk lebih siap dan peka saat terjun ke masyarakat. Selain itu, Charity Act dapat dibuat lebih menarik, atraktif, dan kreatif. Para akademia harus mampu untuk memikirkan konsep acara yang tidak hanya acara tahunan, tetapi sebuah acara yang dapat saling memberikan keuntungan bagi semua pihak. Oleh sebab itu, saran yang dapat diberikan untuk Charity Act ke depannya adalah kerja sama di dalam tim yang perlu ditingkatkan, konsep Charity Act yang bisa dibuat menarik, atraktif, dan kreatif, serta membangun komunikasi internal dan eksternal secara lebih baik. Harapan ke depannya, Charity Act dapat menjadi wadah yang sungguh-sungguh membantu akademia untuk siap terjun ke masyarakat sehingga akademia tidak hanya memperoleh teori atau konsep, tetapi juga mengaplikasikannya dalam kehidupan sehari-hari. Kesimpulan terhadap pelaksanaan kegiatan PKM, antara lain, adalah tingkat ketercapaian kegiatan PKM, dampak dan manfaat kegiatan PKM yang sudah terlihat, dan rekomendasi yang dapat diberikan bagi kegiatan serupa atau lanjutan pada masa depan.

\section{Daftar Pustaka}

Amstrong, P. (2001). Bloom's Taxonomy. Diakses dari https://cft.vanderbilt.edu/guidessub-pages/blooms-taxonomy/ tanggal 29 September 2019.

McLeod, S. (2018). Simply Psychology: Erik Erikson's Stages of Psychosocial Development. Diakses dari https://www.simplypsychology.org/Erik-Erikson.html 28 September 2019.

The Performance Juxtaposition Site. (1995a). Bloom's Taxonomy of Learning Domains. Diakses dari http://www.nwlink.com/ - donclark/hrd/bloom.html tanggal 29 September 2019.

The Performance Juxtaposition Site. (1995b). Bloom's Taxonomy: The Psychomotor Domain. Diakses dari http://www.nwlink.com/ - donclark/hrd/bloom.html tanggal 2 Oktober 2019.

Slavin, R. E. (2006). Educational Psychology: Theory And Practice ( $8^{\text {th }}$ Ed.). New York: Pearson Education, Inc. 